Article

\title{
A Phenological Approach to Spectral Differentiation of Low-Arctic Tundra Vegetation Communities, North Slope, Alaska
}

\author{
Alison Leslie Beamish ${ }^{1, *}$, Nicholas Coops ${ }^{2}$ [D , Sabine Chabrillat $^{3}$ (DD $^{\text {and Birgit Heim }}{ }^{1}$ \\ 1 Alfred Wegener Institute, Helmholtz Centre for Polar and Marine Research, Research Unit Potsdam, \\ Telegrafenberg, A45, 14473 Potsdam, Germany; birgit.heim@awi.de \\ 2 Integrated Remote Sensing Studio (IRSS), Faculty of Forestry, University of British Columbia, \\ 2424 Main Mall, Vancouver, BC V6T 1Z4, Canada; nicholas.coops@ubc.ca \\ 3 Helmholtz Centre Potsdam GFZ German Research Centre for Geosciences, Telegrafenberg, \\ 14473 Potsdam, Germany; chabri@gfz-potsdam.de \\ * Correspondence: abeamish@awi.de
}

Received: 12 October 2017; Accepted: 20 November 2017; Published: 22 November 2017

\begin{abstract}
Arctic tundra ecosystems exhibit small-scale variations in species composition, micro-topography as well as significant spatial and temporal variations in moisture. These attributes result in similar spectral characteristics between distinct vegetation communities. In this study we examine spectral variability at three phenological phases of leaf-out, maximum canopy, and senescence of ground-based spectroscopy, as well as a simulated Environmental Mapping and Analysis Program (EnMAP) and simulated Sentinel-2 reflectance spectra, from five dominant low-Arctic tundra vegetation communities in the Toolik Lake Research Area, Alaska, in order to inform spectral differentiation and subsequent vegetation classification at both the ground and satellite scale. We used the InStability Index (ISI), a ratio of between endmember and within endmember variability, to determine the most discriminative phenophase and wavelength regions for identification of each vegetation community. Our results show that the senescent phase was the most discriminative phenophase for the identification of the majority of communities when using both ground-based and simulated EnMAP reflectance spectra. Maximum canopy was the most discriminative phenophase for the majority of simulated Sentinel-2 reflectance data. As with previous ground-based spectral characterization of Alaskan low-Arctic tundra, the blue, red, and red-edge parts of the spectrum were most discriminative for all three reflectance datasets. Differences in vegetation colour driven by pigment dynamics appear to be the optimal areas of the spectrum for differentiation using high spectral resolution field spectroscopy and simulated hyperspectral EnMAP and multispectral Sentinel-2 reflectance spectra. The phenological aspect of this study highlights the potential exploitation of more extreme colour differences in vegetation observed during senescence when hyperspectral data is available. The results provide insight into both the community and seasonal dynamics of spectral variability to better understand and interpret currently used broadband vegetation indices and also for improved spectral unmixing of hyperspectral aerial and satellite data which is useful for a wide range of applications from fine-scale monitoring of shifting vegetation composition to the identification of vegetation vigor.
\end{abstract}

Keywords: low-Arctic; tundra vegetation; hyperspectral remote sensing; spectroscopy

\section{Introduction}

Arctic tundra ecosystems exhibit small-scale variations in micro-topography as well as significant spatial and temporal variations in soil moisture. As a result, vegetation composition also exhibits 
small-scale heterogeneity leading to, at the community scale, Arctic tundra ecosystems having comparable species diversity to temperate grasslands and coniferous biomes [1]. Areas with common species complexes (i.e., multiple species occurring together) in combination with surface moisture conditions define tundra vegetation communities at the smallest scale, according to the Circumpolar Arctic Vegetation Map [2]. Communities are often broadly divided into moisture regime such as xeric (dry), mesic (moist), or hydric (wet), and soil acidity (acidic, non-acidic) and then further divided depending on the species complexes present [2,3]. Often the same species can be observed in multiple distinct complexes as different phenotypes. Large homogenous patches of one or two species rarely exist outside water tracks, disturbed areas, or dry uplands where erect and prostrate dwarf shrub species dominate. This combination of small-scale heterogeneity in vegetation composition and soil moisture as well as the prostrate nature of tundra species leads to highly mixed, variable, and often similar spectral signatures between distinct vegetation communities. The sometimes dominant presence of non-vascular components (mosses and lichens) and barren areas also contribute to the unique spectral signatures of tundra landscapes [4]. This high spectral similarity can be observed with ground-based Visible-Near Infrared (VNIR) remote sensing data making spectral separation challenging [5-7].

Currently, the broadband Normalized Difference Vegetation Index (NDVI) is the most commonly applied spectral index in Arctic vegetation remote sensing due to the simplicity, availability, and temporal scale of the data [8-10]. NDVI uses reflectance in the red and Near Infrared (NIR) wavelength regions and has been used as a proxy for many parameters of Arctic vegetation such as productivity, biomass, and community classification [11-13]. However, interpretation of NDVI is complex, especially outside of the peak growing season, given the aforementioned spatial and temporal heterogeneity of the biotic (vegetation composition) and abiotic (soil moisture) parameters of tundra ecosystems. Variable moisture conditions, similar canopy structure between some distinct tundra vegetation communities, and an abundance of standing litter all influence spectral reflectance in the NIR, which is sensitive to canopy and leaf cellular structures as well as moisture [14]. Previous research by Buchhorn et al. [6] in low-Arctic Alaska showed that surface moisture masked biomass reflectance in the NIR, indicating that NDVI values in phenological phases or vegetation communities with excessive surface moisture could be problematic. An additional consideration is that of standing litter, a ubiquitous characteristic of tundra vegetation communities, which has shown high reflectance in the NIR, especially in sparsely vegetated communities $[11,15]$.

In the visible range of reflectance (400-700 $\mathrm{nm}$ ), three major vegetation pigment groups absorb strongly in the visible spectrum creating unique spectral signatures and dictating plant colour [16]. Carotenoid pigments that absorb in the blue and short wavelengths of the green spectral region are responsible for absorbing incident radiation and for providing energy to photosynthesis [17,18]. Anthocyanins that absorb strongly in the green and in the short wavelengths of the red spectral region provide photoprotection as well as physical damage protection and influence recovery [19-22]. Both carotenoids and anthocyanins have overlapping absorption regions with chlorophyll absorption, which occurs in the blue and red spectral region, respectively. Chlorophylls are the fundamental photosynthetic pigments that control light absorption by vegetation and in turn control photosynthetic capacity and primary productivity.

Given the seasonal dynamics of the biotic and abiotic parameters influencing spectral reflectance of tundra vegetation communities, it is important to consider how this influence changes over the growing season. Spectral differentiation of tundra vegetation communities at the ground-based scale and, potentially, with remote sensing imagery, could be improved in different phenological phases through targeting specific wavelength regions where spectral differences are maximized and spectral variability is minimized. Previous research of ground-based spectral data has shown that narrow wavelengths (as opposed to broadband representations) in the blue, red, and, red-edge regions of the spectrum are important for differentiation of common Alaskan low-Arctic vegetation communities at early and peak phenological stages, and that the location of the most important spectral 
regions for differentiation shifts with phenophase [7]. These spectral regions are strongly associated with pigment absorption and the observed shifts with phenophase further support the role of pigment production and degradation in detailed assessment of tundra vegetation.

Hyperspectral ground-based remote sensing data are critical for supporting the development and interpretation of optical satellite missions. Accurate and detailed remote sensing of tundra communities will likely improve with the use of hyperspectral remote sensing data such as the upcoming Environmental Mapping and Analysis Program (EnMAP; Deutsches Zentrum für Luft- und Raumfahrt, (DLR)) [23] and the operational, multispectral Sentinel-2 mission [24]. These two platforms represent new tools in Arctic vegetation remote sensing by combining improved spatial resolution and revisit rate (Sentinel-2: 10-20 m and five-day revisit rate with a constellation of two satellites) and spectral resolution to the freely available pool of remote sensing data. The operational Sentinel-2 satellites have 8 bands in the VNIR (490-865 nm) at a spatial resolution between $10 \mathrm{~m}$ and $20 \mathrm{~m}$, and it is particularly promising for accurate tundra vegetation monitoring due to several narrow spectral bands within the red-edge wavelength region ( 20-30 nm width at $705 \mathrm{~nm}, 740 \mathrm{~nm}, 783 \mathrm{~nm}$, and $865 \mathrm{~nm})$. EnMAP will have a total of 89 narrow continuous and contiguous bands ( $\sim 6.5 \mathrm{~nm}$ width) in the VNIR at a spatial resolution of $30 \mathrm{~m}$ with a nominal revisit time of 27 days and an across track off-nadir pointing revisit time of 4 days. Detailed assessment of tundra vegetation that can be provided by these platforms will help to improve our understanding of the impacts of global change on tundra vegetation change from photosynthetic activity to shifting species composition.

In the following study we use ground-based VNIR spectral measurements collected at the canopy level in three major phenophases to investigate the spectral variability within and between dominant Arctic tundra vegetation communities and how this changes over the growing season. We also investigate the spectral variability of dominant communities with broader spectral resolution using simulated Sentinel-2 and simulated EnMAP spectral reflectance data. For this, the InStability Index (ISI) was calculated, a ratio of within and between endmember spectral variability at leaf-out, maximum canopy, and senescence, representing the start, middle, and end of the growing season, in a low-Arctic tundra ecosystem. The ISI is a relatively new technique used as a first step in reducing spectral dimensionality of hyperspectral data before classification methods such as spectral angle mapper [25-29] and has not yet been applied in Arctic tundra ecosystems. Based on the ISI calculations, this paper focuses on (1) the identification of the most discriminative (i.e., low within endmember variability and high between endmember variability) phenophase for identifying dominant vegetation communities; (2) within the most discriminative phenophase, identification of the most discriminative wavelength regions for identification of dominant vegetation communities; (3) determination of how the ISI results differ between ground-based and simulated recent and upcoming satellite (EnMAP, Sentinel-2) reflectance spectra.

\section{Materials and Methods}

\subsection{Study Site and Low-Arctic Vegetation Types}

The study was conducted in the Toolik Lake Research Natural Area (TLRNA) $\left(68^{\circ} 62.57^{\prime} \mathrm{N}\right.$, $\left.149^{\circ} 61.43^{\prime} \mathrm{W}\right)$, which lies in the Kuparuk River watershed on the North Slope of the Brooks Range, Alaska. The TLRNA is representative of the Southern Arctic Foothills, a physiographic province of the North Slope [30] with a combination of moist tussock tundra, wet sedge meadows and dry upland heaths. Data collection took place in a subset of the Toolik Vegetation Grid, a $1 \mathrm{~km}^{2}$, long-term monitoring site established by the National Science Foundation (NSF) as part of the Department of Energy's R4D (Response, Resistance, Resilience, and Recovery to Disturbance in Arctic Ecosystems) project (Figure 1). The elevation of the Toolik Vegetation Grid ranges from 715-775 $\mathrm{m}$ a.s.l. with minimal changes in slope and aspect. Long-term $1 \times 1 \mathrm{~m}$ monitoring plots are located beside equally spaced markers $(100 \mathrm{~m})$ delineating the intersection of the Universal Transverse Mercator (UTM) coordinates of the study area. The $1 \times 1 \mathrm{~m}$ plots are representative of a single vegetation community at 
each site marker covering several square meters. The plots are classified based on work by the Alaska Geobotany Center (http://www.arcticatlas.org/maps/themes/t15c/tl5cvg) and the Circumpolar Arctic Vegetation Map [2]. For the purpose of this study, we grouped the distinct communities as defined by the Alaska Geobotany Center into broader communities based on descriptions in Bratsch et al. [7]. These groups include moist acidic tussock tundra (MAT), moist non-acidic tundra (MNT), shrub tundra (ST), and mossy tussock tundra (MT). We added a fifth group of dry tundra (DT) to this analysis. Additionally, our definition of ST differed slightly as we restricted our measurements to communities with erect dwarf-shrubs Salix pulchra and Betula nana, while Bratsch et al. [7] included measurements of the erect shrub Salix alaxensis and an erect phenotype of Betula nana. Descriptions of the broad communities based on Bratsch et al. [7], descriptions of the distinct vegetation communities, and percentage cover within the Toolik Vegetation Grid, based on data provided by the Alaska Geobotany Center are presented in Table 1. Within the Toolik Vegetation Grid, the sampled vegetation communities make up $73 \%$ of the total vegetation cover and the abundances of each community within the grid are representative of larger areas in the Alaskan low-Arctic [13,31,32], and can be used for extrapolation to larger scale observations such as from satellite imagery at $10 \mathrm{~m}, 20 \mathrm{~m}$ or $30 \mathrm{~m}$.

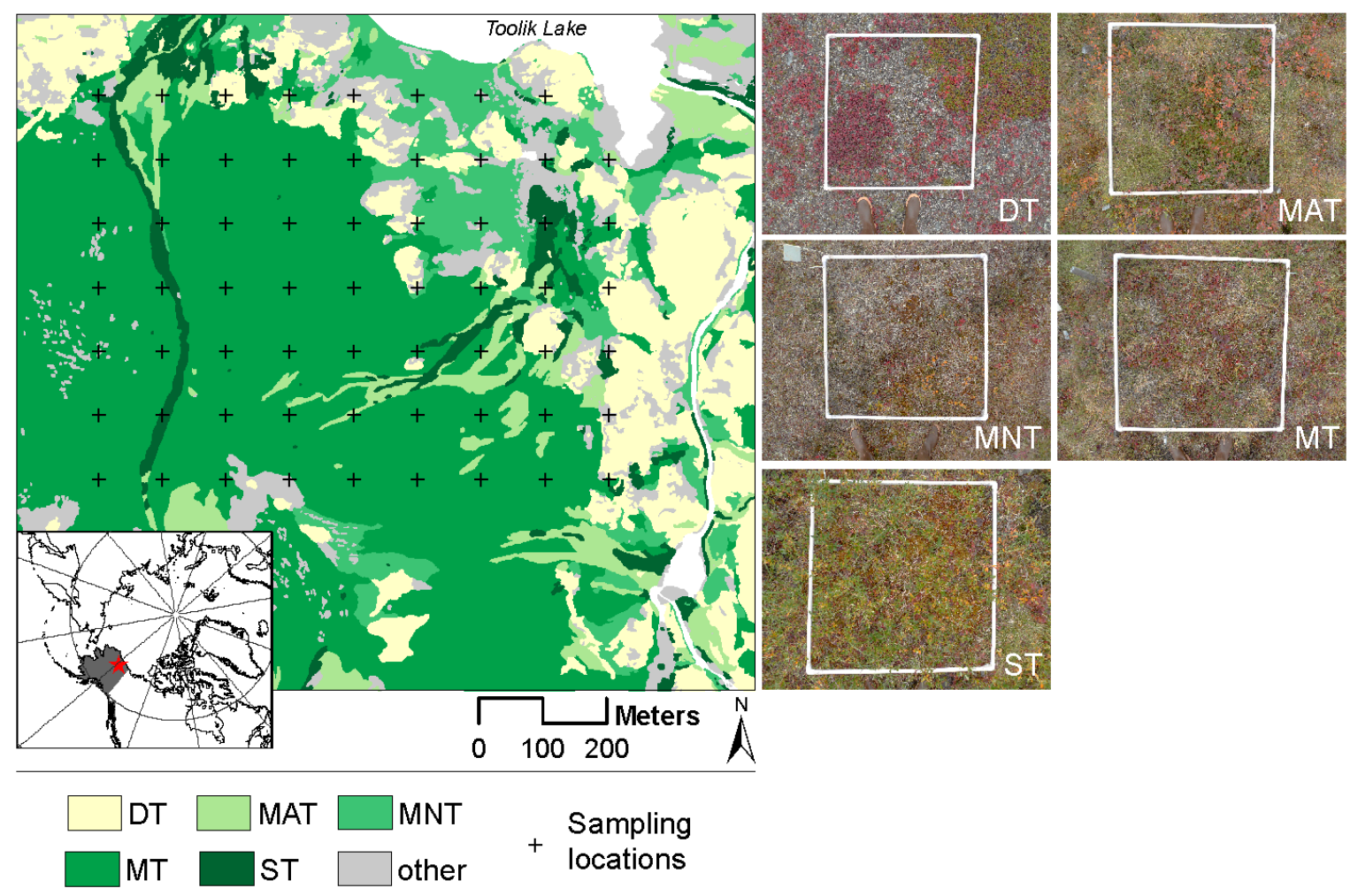

Figure 1. Sampling area within the Toolik Lake Research Natural Area $\left(68^{\circ} 62.57^{\prime} \mathrm{N}, 149^{\circ} 61.43^{\prime} \mathrm{W}\right)$. Colours represent the aggregated vegetation communities as defined in Bratsch et al. [7]. Insets represent typical senescent stage photographs of the five vegetation communities, and the white frame represents a $1 \times 1 \mathrm{~m}$ sampling area. DT: Dry tundra, MAT: Moist acidic tussock tundra, MNT: Moist nonacidic tundra, MT: Mossy tussock tundra, ST: Shrub tundra. Each black cross represents the location of the intersection of Universal Transverse Mercator (UTM) coordinates of the study area with a $1 \times 1 \mathrm{~m}$ long-term monitoring plot near to where ground-based spectral data were collected. 
Table 1. Detailed descriptions of the vegetation communities as defined by Bratsch et al. [7] and the sub-communities included as defined by the Alaska Geobotany Center. \% cover refers to the percentage cover of each community type within the $1 \times 1 \mathrm{~km}$ Toolik Vegetation Grid.

\begin{tabular}{|c|c|c|c|c|}
\hline Community & Description & Sub-Community & Description & $\%$ Cover \\
\hline Dry tundra & $\begin{array}{l}\text { Upland sparsely vegetated areas with } \\
\text { prostrate dwarf shrubs (Salix glauca) and } \\
\text { abundant lichens }\end{array}$ & Dry tundra & $\begin{array}{l}\text { Dryas octopetala-Selaginella sibirica, Dryas octopetala-Salix glauca: } \\
\text { Prostrate dwarf-shrub, forb, fruticose-lichen tundra. Xeric, acidic, } \\
\text { windblown or shallow winter snow cover, stony or with considerable } \\
\text { bare soil. Ridge crests, dry river terraces. Dominated by Dryas } \\
\text { octopetala, occasionally with Salix glauca. }\end{array}$ & 4.2 \\
\hline \multirow{2}{*}{$\begin{array}{l}\text { Moist acidic } \\
\text { tussock tundra }\end{array}$} & \multirow{2}{*}{$\begin{array}{l}\text { Occurs on soils with } \mathrm{pH}<5.0-5.5 \text { and is } \\
\text { dominated by dwarf erect shrubs such as } \\
\text { Betula nana and Salix pulchra, graminoids } \\
\text { species (Eriophorum vaginatum) and } \\
\text { acidophilous mosses }\end{array}$} & $\begin{array}{l}\text { Shrubby tussock tundra } \\
\text { dominated by Betula nana }\end{array}$ & $\begin{array}{l}\text { Betula nana-Eriophorum vaginatum. Dwarf-shrub, sedge, moss tundra } \\
\text { (shrubby tussock tundra dominated by dwarf birch, Betula nana). } \\
\text { Mesic to subhygric, acidic, moderate snow. Lower slopes and } \\
\text { water-track margins. Mostly on Itkillik I glacial surfaces. }\end{array}$ & 3.1 \\
\hline & & $\begin{array}{l}\text { Shrubby tussock tundra } \\
\text { dominated by Salix pulchra }\end{array}$ & $\begin{array}{l}\text { Salix pulchra-Carex bigelowii. Dwarf-shrub, sedge, moss tundra } \\
\text { (shrubby tussock tundra dominated by diamond-leaf willow, Salix } \\
\text { pulchra). Subhygric, moderate snow, lower slopes with solifluction. }\end{array}$ & 3.0 \\
\hline $\begin{array}{l}\text { Moist non-acidic } \\
\text { tundra }\end{array}$ & $\begin{array}{l}\text { Dominated by mosses, graminoids } \\
\text { (Carex bigilowii), and prostrate dwarf } \\
\text { shrubs (Dryas integriolia) }\end{array}$ & Moist non-acidic tundra & $\begin{array}{l}\text { Carex bigelowii-Dryas integrifolia, typical subtype; Tomentypnum } \\
\text { nitens-Carex bigelowii, Salix glauca subtype: Nontussock sedge, } \\
\text { dwarf-shrub, moss tundra (moist nonacidic tundra). Mesic to } \\
\text { subhygric, nonacidic (pH > 5.5), shallow to moderate snow. } \\
\text { Solifluction areas and somewhat unstable slopes. Some south-facing } \\
\text { slopes have scattered glaucous willow (Salix glauca). }\end{array}$ & 5.8 \\
\hline $\begin{array}{l}\text { Mossy tussock } \\
\text { tundra }\end{array}$ & $\begin{array}{l}\text { A moist acidic tussock tundra-type } \\
\text { community dominated by sedges } \\
\text { (E. vaginatum) and abundant } \\
\text { Sphagnum spp. }\end{array}$ & $\begin{array}{l}\text { Moist acidic } \\
\text { tussock tundra }\end{array}$ & $\begin{array}{l}\text { Eriophorum vaginatum-Sphagnum; Carex bigelowii-Sphagnum: Tussock } \\
\text { sedge, dwarf-shrub, moss tundra (tussock tundra, moist acidic } \\
\text { tundra). Mesic to subhygric, acidic, shallow to moderate snow, stable. } \\
\text { This unit is the zonal vegetation on fine-grained substrates with } \\
\text { ice-rich permafrost. Some areas on steeper slopes with solifluction } \\
\text { are dominated by Bigelow sedge (Carex bigelowii). }\end{array}$ & 54.2 \\
\hline \multirow[t]{2}{*}{ Shrub tundra } & \multirow{2}{*}{$\begin{array}{l}\text { Dominated by dwarf shrubs Betula nana } \\
\text { and Salix pulchra interspersed with } \\
\text { graminoids, forbs, lichens and mosses }\end{array}$} & $\begin{array}{l}\text { Dwarf shrub tundra } \\
\text { dominated by Betula nana }\end{array}$ & $\begin{array}{l}\text { Betula nana-Rubus chamaemorus. Dwarf-shrub, moss tundra } \\
\text { dominated by dwarf birch (Betula nana). Subhygric to hygric, acidic, } \\
\text { moderate to moderately deep snow. Upland water tracks, margins of } \\
\text { water tracks and lower slope areas. Somewhat drier areas have } \\
\text { abundant lichens. }\end{array}$ & 1.7 \\
\hline & & $\begin{array}{l}\text { Dwarf shrub tundra } \\
\text { dominated by Salix pulchra }\end{array}$ & $\begin{array}{l}\text { Salix pulchra-Sphagnum warnstorfii. Dwarf-shrub or low-shrub tundra } \\
\text { dominated by willows (Salix pulchra). Subhygric, acidic, moderate to } \\
\text { moderately deep snow. Margins of upland water tracks, palsas and } \\
\text { high-centered polygons. }\end{array}$ & 1.1 \\
\hline
\end{tabular}




\subsection{Ground-Based Data and Sampling Protocol}

To capture phenological variations in spectral reflectance, data were collected systematically at three major phenophases representing the start, middle, and end of the growing season in 2015 and 2016 in $1 \times 1 \mathrm{~m}$ plots within the Toolik Vegetation Grid. Spectral data were acquired to correspond to leaf-out (16 June 2016, DOY 168), maximum canopy (7 July 2015, DOY 188 and 11 July 2016, DOY 193), and senescence (22 August 2015, DOY 234 and 17 August 2016, DOY 229). Ground-based phenological observations $(\mathrm{n}=178)$ from the Toolik Field Station Environmental Data Center (https://toolik.alaska.edu/edc/, 2017), which monitors 15 dominant species in the dominant MAT vegetation type, confirm the dates as good approximations of these phenophases. Leaf-out spectral data collection took place two weeks after average first date leaf-out (29 May 2016, DOY 150) accurately capturing the middle of the leaf-out. Maximum canopy data collection took place four days and one week after the average date of the last petal drop in 2015 (3 July, DOY 184) and 2016 (3 July, DOY 185), respectively. By collecting data after most species finished flowering, the maximum canopy signal was likely less contaminated by non-green signals and fell within the time of peak productivity of the ecosystem. Senescence data were collected one month and three weeks after the average date of the first colour change, referring to the first visible signs of senescence in 2015 (18 July, DOY 199) and 2016 (27 July, DOY 209), respectively. The phenophases used in this study are meant to represent the overall state of the vegetation, not specific phenological events such as the first day of the leaf-out, or first day senescence. Leaf-out is intended to capture the period when most of the vegetation has leafed-out but is not yet fully expanded; maximum canopy is intended to capture when most of the vegetation has fully expanded; senescence is intended to capture when most of the vegetation has experienced a colour change.

Spectral radiance measurements were collected using a GER 1500 field spectrometer (350-1050 nm; 512 bands, spectral resolution $3 \mathrm{~nm}$, spectral sampling $1.5 \mathrm{~nm}$, and $8^{\circ}$ field of view). Spectra were collected under clear weather conditions at the highest solar zenith angle between 10:00 and 14:00 local time. Data were collected at nadir approximately $1 \mathrm{~m}$ off the ground resulting in a Ground Instantaneous Field of View (GIFOV) of approximately $15 \mathrm{~cm}$ in diameter. Nine point measurements of upwelling radiance $\left(\mathrm{L}_{\text {up }}\right)$ were collected in $1 \times 1 \mathrm{~m}$ plots representative of the five vegetation communities and averaged to characterize the spectral variability and to reduce noise. Downwelling radiance $\left(\mathrm{L}_{\text {down }}\right)$ was measured as the reflectance from a white Spectralon $\odot$ plate. Surface reflectance (R) was processed as $\mathrm{L}_{\mathrm{up}} / \mathrm{L}_{\text {down }} \times 100(0-100 \%)$. Reflectance spectra were preprocessed with a Savitzky-Golay smoothing filter $(n=11)$ and subset to $400-985 \mathrm{~nm}$ to remove sensor noise at the edges of the radiometer detector. The total number of plots and spectral measurements collected over the two years by vegetation community is presented in Table 2 .

Table 2. Number of spectral measurements and independent plots sampled by vegetation community.

\begin{tabular}{ccc}
\hline Community & Spectral Measurements & Distinct Plots \\
\hline Dry tundra & 63 & 7 \\
Moist acidic tussock tundra & 126 & 17 \\
Moist non-acidic tundra & 144 & 14 \\
Mossy tussock tundra & 153 & 16 \\
Shrub tundra & 126 & 14 \\
\hline
\end{tabular}

A continuum removal transformation of the ground-based reflectance spectra was conducted using the transform_speclib function in the hsdar package [33] in R Studio (R Core Team, 2015). This process normalizes reflectance spectra to a common baseline for comparison of absorption features. The removal of the continuum slope corrects the band minimum to the true band centre enhancing absorption features [34]. A segmented hull continuum line was generated connecting local maxima of the reflectance spectra. The segmented hull continuum approach was applied in this analysis because 
it is superior in identifying small absorption features [35]. Band depth $\left(\mathrm{BD}_{\lambda}\right)$ was calculated for each absorption feature using the following equation:

$$
B D_{\lambda}=1-\frac{R_{\lambda}}{C V_{\lambda}}
$$

where $R$ is the continuum removed reflectance at wavelength $\lambda$; and $C V$ is the continuum value at wavelength $\lambda$. The maximum band depth was calculated as the maximum band depth between a specified wavelength range.

\subsection{EnMAP and Sentinel-2 Surface Reflectance Simulation}

The upcoming EnMAP satellite will have a total of 242 bands (423-2450 nm) with a spectral resolution between $6.5 \mathrm{~nm}$ and $10 \mathrm{~nm}$, from which 95 spectral bands are within the spectral range of the GER field spectroradiometer. The GER ground-based surface reflectance spectra were interpolated to $1 \mathrm{~nm}$ and then spectrally resampled using the spectral response curves of the 95 VNIR EnMAP spectral bands to produce surface reflectance data commensurate with the EnMAP sensor. The Sentinel-2 satellite has 13 spectral bands $(443-2190 \mathrm{~nm})$ with a spectral resolution between $15 \mathrm{~nm}$ and $120 \mathrm{~nm}$, from which the first 10 bands (band 1-8, 8a, 9) covered the spectral range of the GER radiometer. Data were simulated in the same way as the EnMAP procedure; interpolated to $1 \mathrm{~nm}$ and resampled using the spectral response curves of the 10 VNIR Sentinel-2 bands.

\subsection{Stable Wavelength Identification Using the InStability Index}

The ground-based reflectance spectra as well as the spectrally simulated EnMAP and Sentinel-2 reflectance spectra were used to calculate the InStability Index (ISI) in order to identify discriminative wavelengths in differentiating dominant tundra vegetation communities [27,36]. ISI comes from a classification method known as stable zone unmixing (SZU), a spectral mixture analysis used to determine fractional cover of endmembers in a pixel [27]. ISI has been applied to hyperspectral imagery to create spectral subsets of data to map spectrally similar invasive species and detect oil spills $[25,26,29]$. The ISI is a ratio index calculated for each wavelength over the entire spectral range of the within-class variability and the between-class variability. We used ISI to explore which regions of the spectra are most discriminative for differentiation, i.e., maximizing between community variability while minimizing within community variability, and to examine how that changes over the growing season. ISI developed in Somers et al. [36] is calculated as follows for two endmembers at wavelength $i$ :

$$
\text { ISI }_{i}=\frac{\Delta_{\text {within }, i}}{\Delta_{\text {between }, i}}=\frac{1.96\left(\sigma_{1, i}+\sigma_{2, i}\right)}{\left|R_{\text {mean }, 1, i}-R_{\text {mean }, 2, i}\right|}
$$

where $R_{\text {mean }, 1, i}$ and $R_{\text {mean }, 2, i}$ are mean reflectance values for endmembers 1 and 2; and $\sigma_{1, i}$ and $\sigma_{2, i}$ are the standard deviations of the reflectance values. Somers et al. [36] defined the sum of the standard deviation of endmembers 1 and 2 as an appropriate measure of within class variability and the average Euclidean distance between endmembers as an appropriate measure of between class variability. This equation was expanded to a multiple endmember scenario used in this study as follows:

$$
I_{S I}=\frac{\Delta_{\text {within }, i}}{\Delta_{\text {between }, i}}=\frac{m}{m(m-1)} \times \sum_{z=1}^{m-1} \sum_{j=z+1}^{m} \frac{1.96\left(\sigma_{\mathrm{z}, i}+\sigma_{\mathrm{j}, i}\right)}{\left|R_{\text {mean }, \mathrm{z}, \mathrm{i}}-R_{\text {mean }, \mathrm{j}, i}\right|}
$$

where $m$ is the total number of vegetation communities $(\mathrm{n}=5)$; and $z$ and $j$ are the vegetation communities under consideration when comparing more than two communities. To calculate ISI values for each of the five communities, $z$ was held constant as the target vegetation community and $j$ alternated between the four remaining communities as described in Equation (1). These four sets of ISI values were then summed by wavelength and multiplied by the multiple endmember correction factor $m / m(m-1)$ to get the final ISI value of each community. Low ISI values indicate 
low within-community spectral variability compared to between-community spectral variability and discriminative wavelengths.

A second step was taken to identify the most discriminative wavelengths using a three-wavelength moving window to identify local minima. The local minima were identified using a three-wavelength moving window minimum approach. Previous research has shown that ISI-selected wavelength subsets increase the accuracy of endmember detection in spectrally similar surfaces [26,27]. The ISI local minimum technique allows for flexible adjustment based on the variability of specific parts of the spectrum, i.e., the local minima technique does not penalize or omit more variable parts of the spectrum just because they are highly variable. To simulate how wavelength selection could differ with different spectral resolutions, the local minima technique was performed on the simulated EnMAP and simulated Sentinel-2 reflectance spectra and compared to ground-based data. While Sentinel- 2 is not a hyperspectral instrument it has higher spectral resolution in the red-edge spectral region than previous multispectral optical missions.

The selected wavelengths were then partitioned into five broad spectral regions to identify the most influential ones based on known pigment absorption regions and canopy structure. The five broad spectral regions considered were defined as: blue: 400-500 nm, absorption of chlorophylls and carotenoids; green: 500-600 nm, anthocyanin absorption; red: 600-680 nm, absorption of chlorophylls; red-edge transition: $680-800 \mathrm{~nm}$; and NIR: $801-985 \mathrm{~nm}$, leaf/canopy structure and water absorption.

\section{Results}

\subsection{Spectral Characteristics by Phenophase}

The smoothed and averaged reflectance spectra indicate that the five tundra vegetation communities are relatively similar spectrally within each phenophase and between leaf-out and senescence. Leaf-out and senescence spectra both present flatter spectra compared to maximum canopy and less pronounced absorption in the red wavelength region (Figure 2). MNT had the most distinct reflectance spectra with notably lower reflectance in the NIR in all three phenophases (Table 3). DT had the greatest NIR reflectance at leaf-out and senescence while MAT and ST had the highest reflectance in the NIR at maximum canopy. At leaf-out all communities except the xeric DT site showed absorption around $750 \mathrm{~nm}$ and $980 \mathrm{~nm}$, at two water-absorption wavelength regions. The chlorophyll and carotenoid absorption region between $400 \mathrm{~nm}$ and $500 \mathrm{~nm}$ and chlorophyll absorption region around $680 \mathrm{~nm}$ were deepest at maximum canopy in all communities. Reflectance in the NIR plateau from approximately $750 \mathrm{~nm}$ to $985 \mathrm{~nm}$ and absorption at the water-absorption region around $920 \mathrm{~nm}$ were also highest at maximum canopy in all communities except DT. The greatest difference in spectral reflectance in the visible spectrum appears around the $680 \mathrm{~nm}$ chlorophyll-absorption region in all three phenophases. Characteristic changes in the slope of the red-edge transition between $681 \mathrm{~nm}$ and $800 \mathrm{~nm}$ known as the "blue shift" of stressed vegetation [37] were observed from leaf-out to maximum canopy and maximum canopy to senescence for all communities. 

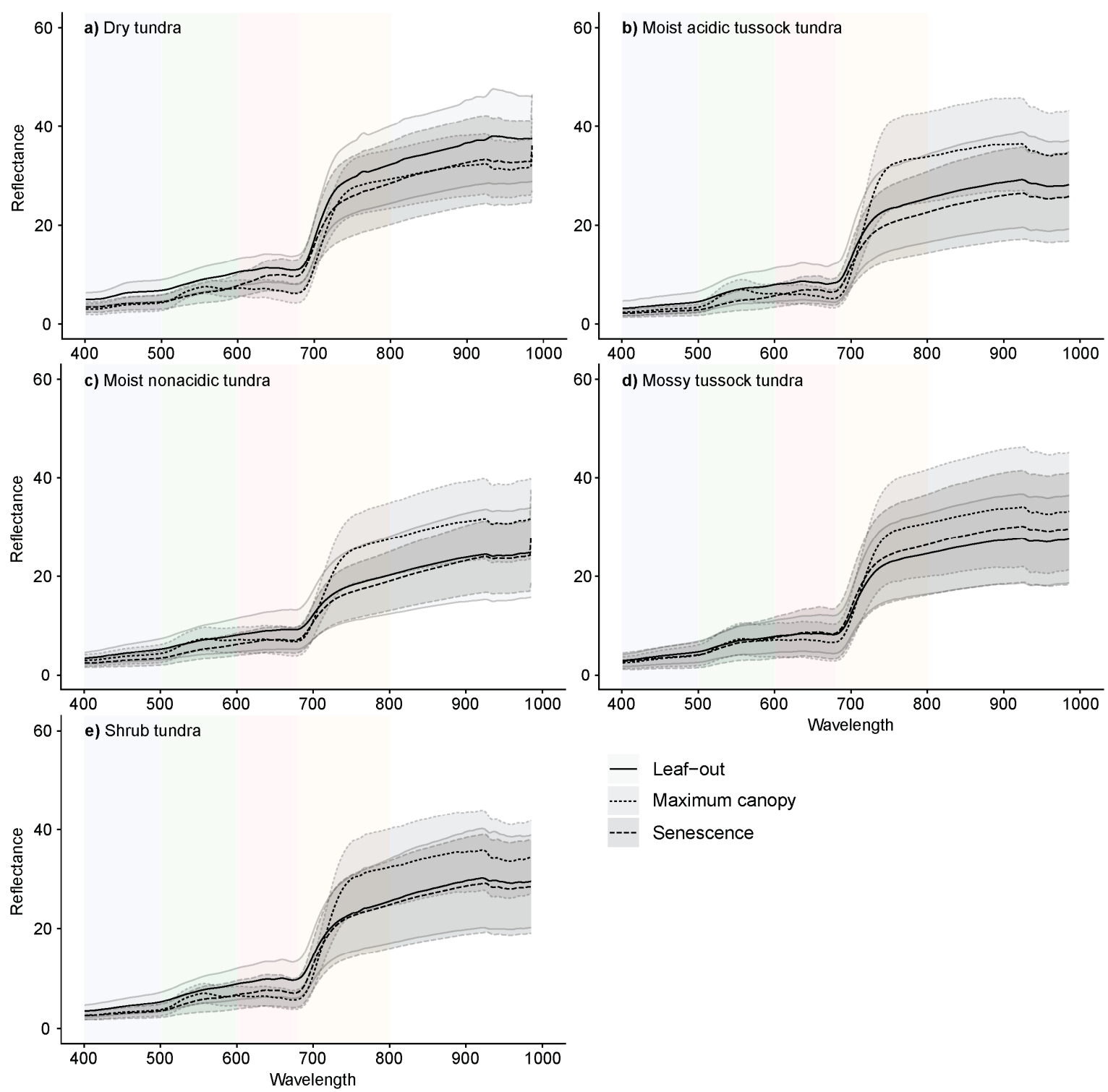

Figure 2. Mean (black line) and standard deviation (grey ribbon) of ground-based reflectance spectra of five dominant tundra vegetation communities in three major phenophases of leaf-out, maximum canopy, and senescence. (a) dry tundra; (b) moist acidic tussock tundra; (c) moist non-acidic tundra; (d) mossy tussock tundra; (e) shrub tundra. 
Table 3. Metrics of ground-based reflectance spectra of five dominant tundra vegetation communities in three major phenophases: leaf-out, maximum canopy, and senescence.

\begin{tabular}{|c|c|c|c|c|c|c|c|}
\hline \multirow[b]{2}{*}{ Vegetation Community } & \multirow[b]{2}{*}{ Date } & \multirow{2}{*}{$\begin{array}{c}\text { Red Edge Inflection Point } \\
\text { Wavelength }(\mathrm{nm})\end{array}$} & \multicolumn{3}{|c|}{ Max Reflectance } & \multicolumn{2}{|c|}{ Max Continuum Removed Band Depth } \\
\hline & & & $550 \mathrm{~nm}(\%)$ & 750 nm (\%) & $920 \mathrm{~nm}(\%)$ & Blue $(400-550 \mathrm{~nm})$ & $\operatorname{Red}(550-750 \mathrm{~nm})$ \\
\hline \multirow{3}{*}{ Dry tundra } & Leaf-out & 706 & 9.28 & 32.35 & 40.54 & 0.13 & 0.38 \\
\hline & Maximum canopy & 710 & 9.01 & 31.54 & 37.10 & 0.26 & 0.64 \\
\hline & Senescence & 704 & 7.33 & 36.28 & 44.19 & 0.21 & 0.37 \\
\hline \multirow{3}{*}{ Moist acidic tussock tundra } & Leaf-out & 706 & 10.08 & 32.19 & 37.70 & 0.20 & 0.41 \\
\hline & Maximum canopy & 714 & 10.35 & 39.45 & 46.08 & 0.45 & 0.74 \\
\hline & Senescence & 705 & 6.82 & 28.03 & 37.37 & 0.28 & 0.42 \\
\hline \multirow[t]{2}{*}{ Moist non-acidic tundra } & Maximum canopy & 712 & 9.33 & 28.97 & 35.08 & 0.25 & 0.56 \\
\hline & Senescence & 704 & 6.52 & 22.49 & 33.42 & 0.24 & 0.31 \\
\hline \multirow{3}{*}{ Mossy tussock tundra } & Leaf-out & 708 & 8.78 & 27.68 & 32.71 & 0.16 & 0.38 \\
\hline & Maximum canopy & 713 & 8.94 & 32.20 & 39.76 & 0.29 & 0.62 \\
\hline & Senescence & 707 & 8.86 & 29.31 & 34.59 & 0.24 & 0.40 \\
\hline \multirow{3}{*}{ Shrub tundra } & Leaf-out & 704 & 8.75 & 25.16 & 31.87 & 0.22 & 0.33 \\
\hline & Maximum canopy & 714 & 8.10 & 30.96 & 37.61 & 0.38 & 0.70 \\
\hline & Senescence & 705 & 6.09 & 26.24 & 33.65 & 0.26 & 0.46 \\
\hline
\end{tabular}




\subsection{InStability Index and Wavelength Selection of Ground-Based Spectra}

We used the ISI to examine the spectral variability by wavelength between vegetation communities at leaf-out, maximum canopy, and senescence (Table 4, Figure 3). Table 4 shows that when examining the entire VNIR reflectance spectrum, senescence appears to be the most discriminative phenophase, related to relatively higher between-community variability versus within-community variability for differentiation of target vegetation communities according to cumulative ISI values. MAT, MT, and ST all had the lowest cumulative ISI values during senescence while DT and MNT had lowest cumulative ISI values at leaf-out and maximum canopy, respectively.

Figure 3 shows that at leaf-out, ISI values were consistently low at around $750 \mathrm{~nm}$, but otherwise ISI values by wavelength showed large differences between communities. At maximum canopy, wavelengths $>450 \mathrm{~nm}$ in the blue reflectance spectrum had consistently low ISI values, and at senescence the entire blue spectrum had consistently low ISI values across all communities. At senescence, the water-absorption region at the end of the NIR between $920 \mathrm{~nm}$ and $985 \mathrm{~nm}$ had relatively low and stable ISI values in every community. Wavelengths around $700 \mathrm{~nm}$, the beginning of the red edge, had low ISI values (discriminative) in all communities and all phenophases. Leaf-out and maximum canopy had the most variable NIR ISI values, while at senescence values were consistently low except for single ISI peaks in the MT and MNT communities. Figure 3 also presents the results from the local minima technique applied to the ISI values per wavelength for the dominant tundra communities in all three phenophases.

At leaf-out, in all communities except DT, the minima technique chose a discriminative wavelength within $6 \mathrm{~nm}$ of $440 \mathrm{~nm}$, a region of strong chlorophyll and carotenoid absorption in the blue wavelength region (Figure 3(2)). In the same communities a wavelength was selected between $660 \mathrm{~nm}$ and $680 \mathrm{~nm}$, a region recognized as an absorption maximum of chlorophyll in the red spectrum, and one within $4 \mathrm{~nm}$ of $750 \mathrm{~nm}$, the end of the red-edge transition where vegetation cellular structure drives the reflectance signal. In MT, MAT, and ST, a wavelength was selected within $6 \mathrm{~nm}$ of the $550 \mathrm{~nm}$ "green reflectance peak", a region with no chlorophyll absorption and anthocyanin absorption. In DT the majority of wavelength selection was in the NIR, not surprisingly given the sparse vascular plant cover and xeric moisture regime in this vegetation community. Wavelength selection was high in MAT, ST, and DT in the water-absorption NIR region between $920 \mathrm{~nm}$ and $985 \mathrm{~nm}$.

At maximum canopy, in all communities including DT, the minima technique selected a wavelength within the 660-680 $\mathrm{nm}$ chlorophyll-absorption region in the red spectrum. In all communities, exactly $707 \mathrm{~nm}$ was selected by the minima technique, a wavelength in the middle of the red edge and just after chlorophyll absorption stops and vegetation cellular structure takes over the reflectance signal. Additionally, a wavelength was selected within $4 \mathrm{~nm}$ of $950 \mathrm{~nm}$ in the water-sensitive NIR region in all communities. In MT, MAT, and ST, a wavelength was selected within $6 \mathrm{~nm}$ of the $550 \mathrm{~nm}$ "green peak".

At senescence in all communities, the minima technique selected $960 \mathrm{~nm}$ which lies within the water-absorption region between $920 \mathrm{~nm}$ and $985 \mathrm{~nm}$, and in all communities except DT a wavelength was selected within $2 \mathrm{~nm}$ of $750 \mathrm{~nm}$ in the end of the red-edge transition. In MAT, MNT, and MT, a wavelength was selected within $4 \mathrm{~nm}$ of $440 \mathrm{~nm}$, the chlorophyll and carotenoid absorption region and in MAT, MNT, and ST a wavelength was selected between $660 \mathrm{~nm}$ and $680 \mathrm{~nm}$, the second chlorophyll-absorption region. The minima technique selected no wavelengths near the $550 \mathrm{~nm}$ "green peak". 

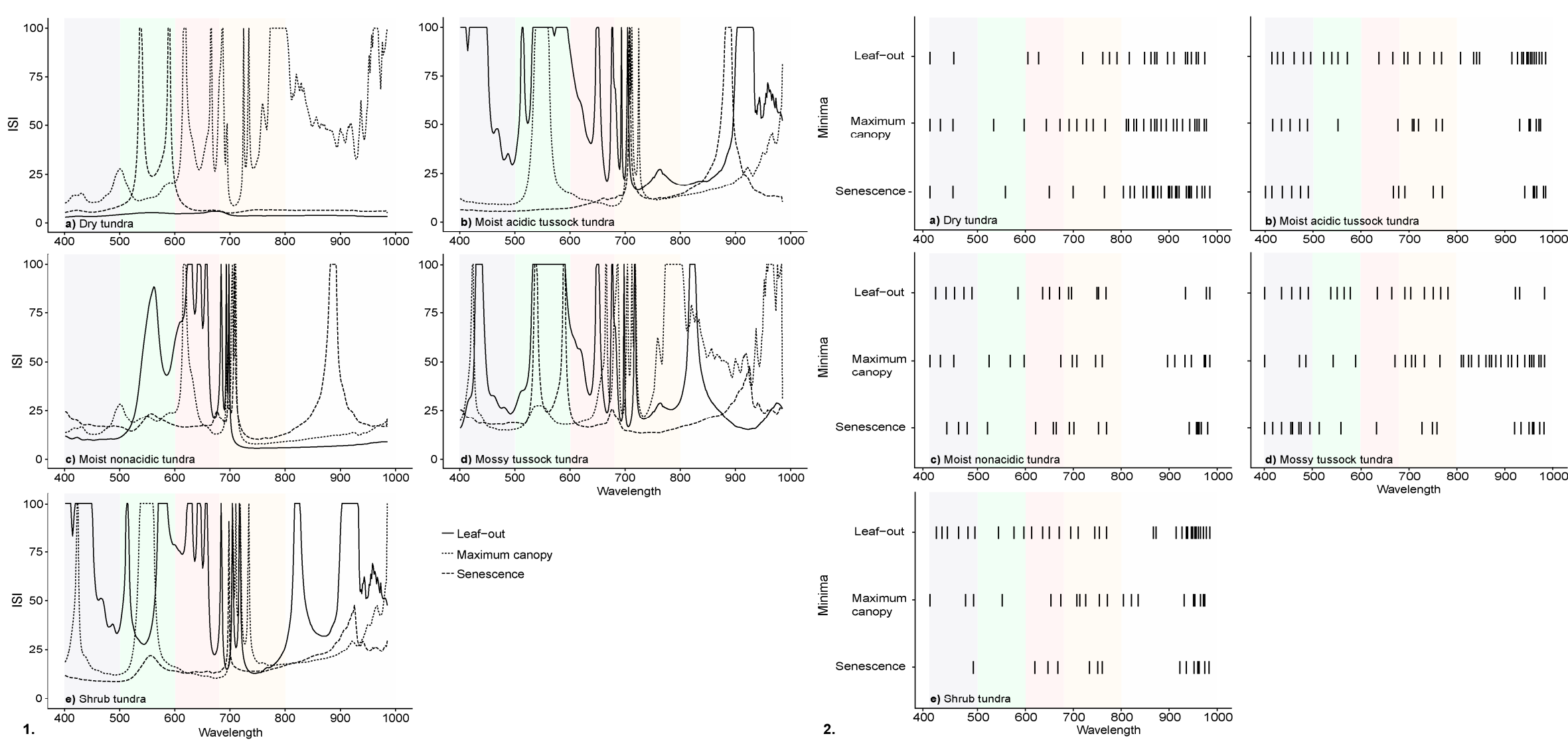

Figure 3. 1. Ground-based Instability Index (ISI) analyses: ISI values per wavelength and 2. results of the ground-based ISI minima wavelength selection of five dominant tundra vegetation communities: (a) dry tundra; (b) moist acidic tussock tundra; (c) moist non-acidic tundra; (d) mossy tussock tundra; (e) shrub tundra; in the three major phenophases of leaf-out, maximum canopy, and senescence. Background colors represent the five broad spectral regions considered for interpretation, associated with different pigments and chlorophyll absorptions. For visualization purposes, all ISI values greater than 100 were set to 100. 
Table 4. Cumulative ISI values of ground-based spectra of five dominant tundra vegetation communities: leaf-out, maximum canopy, and senescence. Bold values represent minimum cumulative values.

\begin{tabular}{cccc}
\hline Vegetation Community & Leaf-Out & Maximum Canopy & Senescence \\
\hline & ISI & ISI & ISI \\
\hline Dry tundra & $\mathbf{1 5 3 2}$ & 148,112 & 8477 \\
Moist acidic tussock tundra & 69,256 & 15,867 & $\mathbf{7 7 3 0}$ \\
Moist non-acidic tundra & 26,104 & $\mathbf{7 3 9 3}$ & 9835 \\
Mossy tussock tundra & 38,139 & 150,136 & $\mathbf{1 3 , 0 4 7}$ \\
Shrub tundra & 71,140 & 17,715 & $\mathbf{6 6 2 3}$ \\
\hline
\end{tabular}

\subsection{InStability Index and Wavelength Selection of Simulated Satellite Reflectance Spectra}

Simulated reflectance spectra of EnMAP and Sentinel-2 are shown in Figures S1 and S2. Cumulative ISI values from the simulated EnMAP reflectance spectra had similar phenological trends as ground-based spectra with minimums at senescence for MAT, MT, and ST and minimums at leaf-out and maximum canopy for DT and MNT, respectively (Table 5). The simulated Sentinel-2 reflectance spectra had different phenological results with leaf-out identified as the most discriminative phase for MNT and maximum canopy the most discriminative for MAT, MT, and ST.

Table 5. Cumulative ISI values of simulated EnMAP and simulated Sentinel-2 reflectance spectra of five dominant tundra vegetation communities: leaf-out, maximum canopy, and senescence. Bold values represent minimum cumulative values.

\begin{tabular}{ccccccc}
\hline Vegetation & \multicolumn{2}{c}{ Leaf-Out } & \multicolumn{2}{c}{ Maximum Canopy } & \multicolumn{2}{c}{ Senescence } \\
\hline ISI & EnMAP & Sentinel-2 & EnMAP & Sentinel-2 & EnMAP & Sentinel-2 \\
\hline Dry tundra & $\mathbf{4 0 1}$ & $\mathbf{3 8}$ & 7795 & 155 & 1125 & 53 \\
Moist acidic tussock tundra & 16,789 & 684 & 4570 & $\mathbf{2 2 5}$ & $\mathbf{2 0 5 0}$ & 297 \\
Moist non-acidic tundra & 2834 & $\mathbf{1 2 9}$ & $\mathbf{1 8 8 3}$ & 182 & 2687 & 339 \\
Mossy tussock tundra & 12,958 & 485 & 7933 & $\mathbf{2 1 8}$ & $\mathbf{2 3 4 6}$ & 311 \\
Shrub tundra & 9694 & 807 & 4928 & $\mathbf{2 0 0}$ & $\mathbf{1 7 2 4}$ & 351 \\
\hline
\end{tabular}

ISI values of simulated EnMAP reflectance spectra (Figure 4) showed overall low variability in senescence with some ISI spikes in the green part of the reflectance spectrum and at longer NIR wavelengths. Leaf-out and maximum canopy ISI values were highly variable between vegetation communities. Longer wavelengths in the red-edge and green reflectance spectrum had consistently low values at leaf-out and maximum canopy in all communities, respectively. In Figure 5, it can be observed that the broader resolution Sentinel-2 showed less obvious phenological trends in ISI values by band. In general, the green and red bands had the highest ISI values while the red edge and NIR had the lowest in all communities and phenophases.

The same minima technique was applied to ISI values of simulated satellite data. The results of the simulated EnMAP minima wavelength selection (Figure 4) were comparable to the ground-based data (Figure 3). At leaf-out, there was strong selection in the blue region in all communities except DT. In MAT, MNT, MT, and ST a wavelength was selected between $450 \mathrm{~nm}$ and $460 \mathrm{~nm}$ within the maximum chlorophyll-, carotenoid-absorption region. The minima technique also selected a wavelength between $670 \mathrm{~nm}$ and $680 \mathrm{~nm}$ in the chlorophyll-absorption maximum of the red spectrum region in all communities except DT. In both MNT and ST, wavelengths were selected around $750 \mathrm{~nm}$ where the reflectance signal becomes dominated by leaf cellular and canopy structure. In both MAT and MT, a wavelength was selected at $550 \mathrm{~nm}$ in the "green reflectance peak". As with ground-based data, the majority of wavelength selection in DT occurred in the NIR. The minima technique showed strong wavelength selection in all communities in the water absorption region between $920 \mathrm{~nm}$ and $985 \mathrm{~nm}$, except in MNT which had only one. 

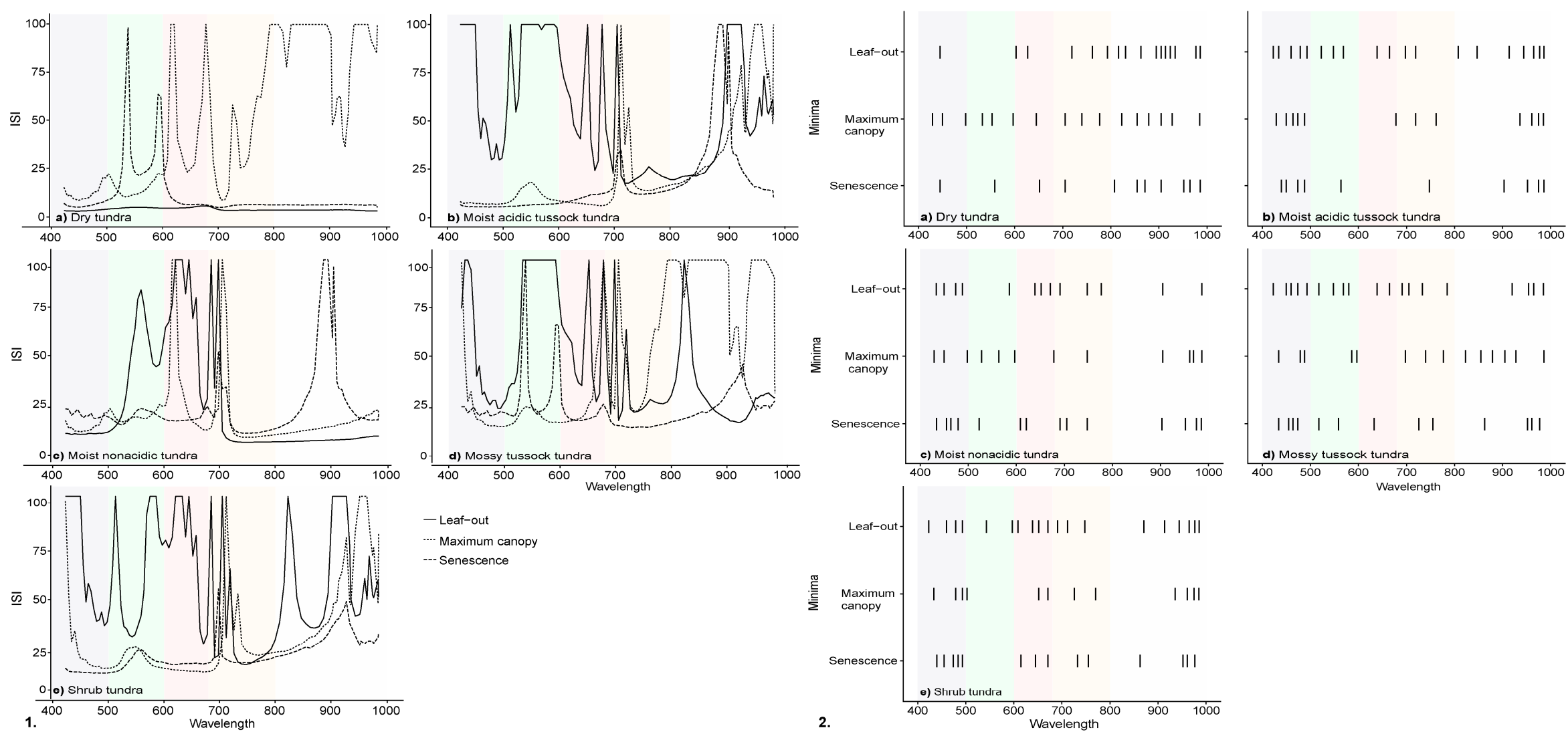

- Leaf-out

-..- Maximum canopy

$\cdots-$ Senescence

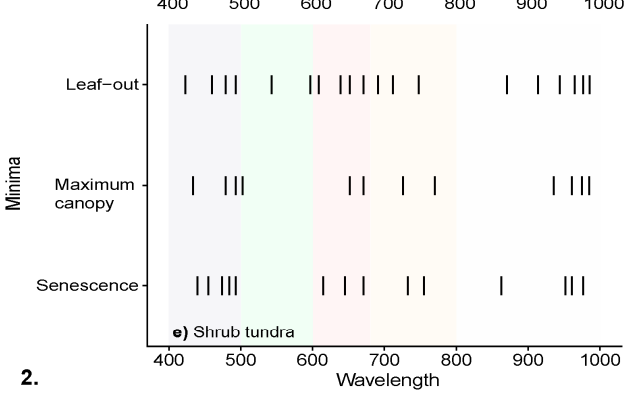

Figure 4. 1. Simulated EnMAP Instability Index (ISI) analyses: ISI values per wavelength and 2. results of the ground-based ISI minima wavelength selection of five dominant tundra vegetation communities in the three major phenophases of leaf-out, maximum canopy, and senescence. Background colors represent the five broad spectral regions considered for interpretation, associated with different pigments and chlorophyll absorptions. For visualization purposes all ISI values greater than 100 were set to 100. (a) dry tundra; (b) moist acidic tussock tundra; (c) moist non-acidic tundra; (d) mossy tussock tundra; (e) shrub tundra. 

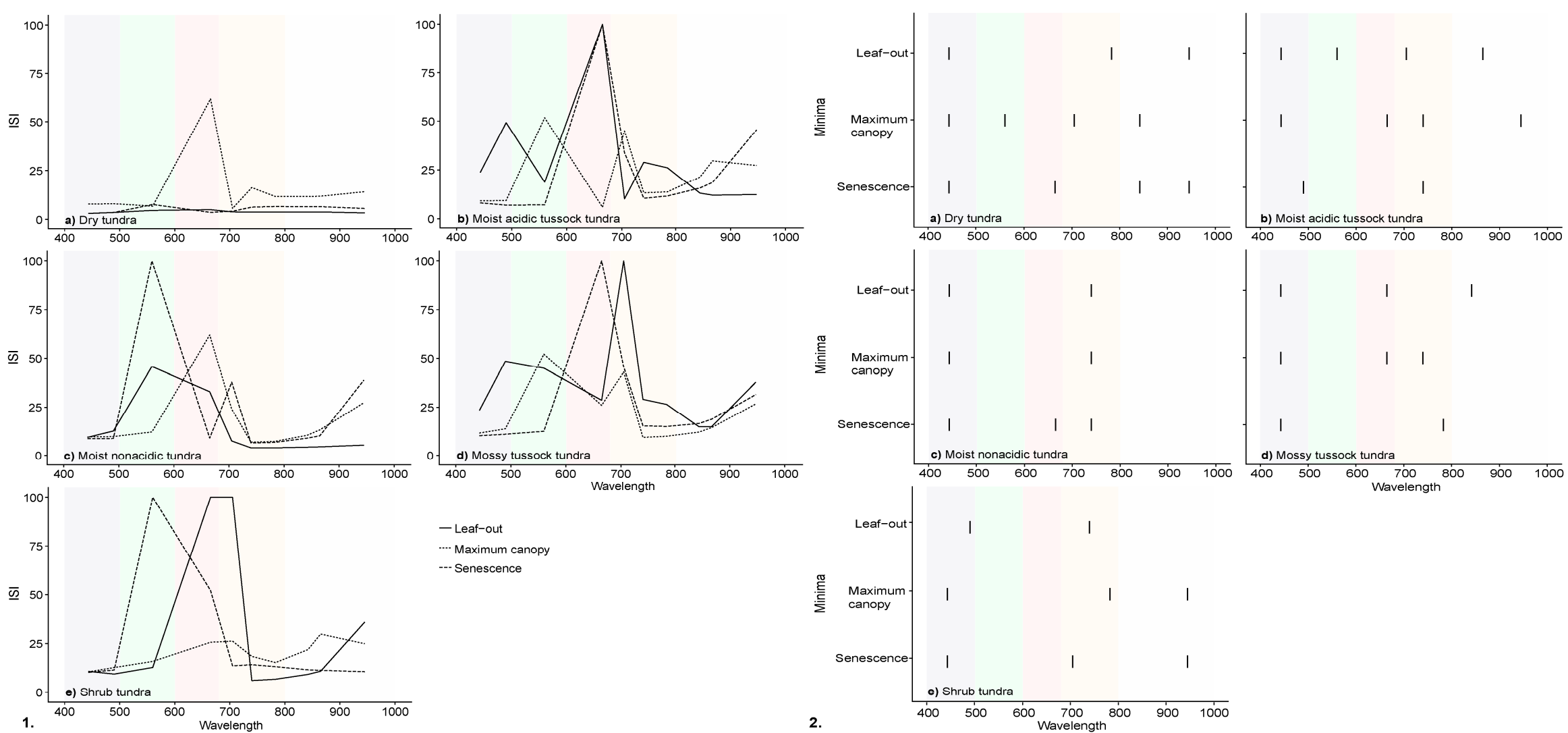

Figure 5. 1. Simulated Sentinel-2 Instability Index (ISI) analyses: ISI values per wavelength and 2. results of the ground-based ISI minima wavelength selection of five dominant tundra vegetation communities in the three major phenophases of leaf-out, maximum canopy, and senescence. Background colors represent the five broad spectral regions considered for interpretation, associated with different pigments and chlorophyll absorptions. For visualization purposes all ISI values greater than 100 were set to 100. (a) dry tundra; (b) moist acidic tussock tundra; (c) moist non-acidic tundra; (d) mossy tussock tundra; (e) shrub tundra. 
At maximum canopy, the minima technique once again had strong selection in the blue spectrum with wavelengths selected at $450 \mathrm{~nm}$ within the maximum chlorophyll- and carotenoid-absorption region in DT, MAT, and MNT. In all communities except MT, a wavelength was selected between $670 \mathrm{~nm}$ and $680 \mathrm{~nm}$ in the red chlorophyll-absorption region. In DT and MT wavelengths around the $550 \mathrm{~nm}$ "green reflectance peak" were selected. As with leaf-out, minima wavelength selection was strong in the water sensitive NIR region between $920 \mathrm{~nm}$ and $985 \mathrm{~nm}$ in all communities.

At senescence in all communities except DT, a wavelength around $750 \mathrm{~nm}$, the end of the red-edge transition, was selected. In all five communities, wavelength $952 \mathrm{~nm}$ was selected in the water sensitive NIR region as well as wavelengths between $440 \mathrm{~nm}$ and $455 \mathrm{~nm}$ within the chlorophylland carotenoid-absorption in the blue spectral region. Minima selection was overall high in the blue spectrum as with the other two phenophases. In DT, MAT, and MT there was consistent wavelength selection around the $550 \mathrm{~nm}$ "green-peak".

The simulated Sentinel-2 data had generally similar band selection (Figure 5) when compared in context to the broad defined spectral regions. At leaf-out, the narrow blue band was selected in all communities except ST, in which the broad blue aerosol band was selected. In all communities, a narrow band in the red edge was selected, except MT, which had the broad NIR band selected. Only in MAT was the narrow NIR band selected, and only in DT was the water vapour NIR band centered at $945 \mathrm{~nm}$ selected.

Similar to leaf-out, the narrow blue band was selected by the minima technique in all communities at maximum canopy. Only in DT was there selection in the green band and in MAT and MT the red band. Narrow red-edge bands were selected in all communities. Only in DT was the broad NIR band selected, and in MAT and ST the water vapour band was selected.

At senescence, the narrow blue aerosol band was selected in all communities and the broad blue band was selected in MAT. There was no band selection in the green reflectance spectrum. In DT and MNT, the red band was selected and all in communities a narrow red-edge band was selected except in DT which had selection in the broad NIR band. In DT and ST, the NIR water-vapour band was selected.

\section{Discussion}

Investigation of the ground-based, as well as the simulated EnMAP and Sentinel-2 spectral variability of five dominant low-Arctic tundra vegetation communities was undertaken using the InStability Index (ISI) at three major phenophases of leaf-out, maximum canopy and senescence at Toolik Lake, Alaska. The ISI index was chosen as a tool to understand the seasonal dynamics of spectral variability and identify the phenophase and regions of the spectrum that are best suited for a detailed assessment of representative tundra communities. In this study, we specifically focus on dominant tundra communities occurring on a circumarctic scale (tundra biomes C, D, E, Walker et al., [2]) excluding the spectrally distinguishable plant communities of wetlands and shrubs taller than half a meter that occur in disturbed areas or sheltered morphology. Previous studies utilize ISI and the minima wavelength technique with hyperspectral imagery as a pre-processing tool for spectral unmixing and classification $[25,29]$, but it is also an effective method to explore and understand the phenology of spectral variability by wavelength. We present a novel result of the influence of phenophase on the variability of Arctic vegetation community reflectance spectra and how in turn this could improve the differentiation of these spectrally similar endmembers.

\subsection{Phenophase and Wavelength Stability of Ground-Based Spectra}

The identification of senescence as the most discriminative phenophase for the majority of vegetation communities is an important finding as mossy tussock tundra, moist acidic tussock tundra, and shrub tundra combined represent $63.1 \%$ of the Toolik Vegetation Grid and contribute greatly to Alaskan above-ground biomass at the ecosystem scale [13,31,32]. The observed discriminability of the senescence phenophase could be explained by a combination of overall lower variability in 
reflectance and/or comparable or greater differences in mean reflectance boosting the differentiability of these three communities from the other communities in comparison to leaf-out and maximum canopy (Table 4 and Figure 3). Previous characterizations of Arctic vegetation community reflectance spectra have suggested that distinct communities are spectrally more similar outside of the peak growing season but have not explicitly explored the influence or trade-off of accompanying spectral variability observed in the late season [6,7]. To date, the late season represents a relatively unexplored phenophase spectrally, and this paper shows that it has potential given the relatively low ISI values in the visible and red-edge spectrum, providing independence from the litter and water-sensitive NIR plateau for characterization.

For the remaining two communities of MNT and DT, making up 10\% of the study area, maximum canopy and leaf-out were the most discriminative phenophases, respectively. For MNT, this is likely due to a maximum difference in chlorophyll absorption. Buchhorn et al. [6] and Walker et al. [38] have shown the "less green" nature of non-acidic communities compared to acidic ones as a result of species composition, including the dominating moss species and a lack of shrub species, leading to lower pigment absorption by chlorophyll $[3,6]$. The discriminability of the leaf-out phenophase for identification of DT could be explained by a combination of sparse vegetation cover and large differences in spectral reflectance during leaf-out. These DT sites are subject to unique early-season conditions as they are generally located on upland, exposed areas and have shallow winter snow cover leading to earlier spring snowmelt and leaf-out of the vascular vegetation dominated by prostrate dwarf shrubs $[2,16,39,40]$. Higher reflectance in the visible and NIR spectrum could be the result of more advanced vegetation phenology in combination with bright, dry surfaces dominated by small stones and lichens which have been shown to drive high reflectance in the NIR [39,40]. The advanced phenology and dessication is supported by the average snowfree date of dry tundra phenology plots, as recorded by the Toolik Environmental Data Centre, which were snow-free 10 and 11 days earlier than moist acidic tussock tundra tundra plots in 2015 and 2016, respectively.

The resulting wavelength selection from the ISI minima technique in the most discriminative phenophase of each community predominantly identifies vegetation colour, driven by vegetation pigment content, as discriminative spectral regions for identification of specific communities. The identification of senescence as a discriminative phenophase is particularly interesting, as the communities are visually most distinct at senescence when carotenoid (yellow to orange) and anthocyanin (red) pigments begin to dominate and chlorophyll (green) pigments are degrading. With the exception of DT, all communities had equal or greater wavelength selection in the combined visible and red-edge spectrum than the NIR. Slope and position of the red edge has been directly related to chlorophyll content in vascular plants [41] and this paper is in agreement with previous and well-established research linking absorption in the visible spectrum to vegetation colour and pigment content [16,42-46] but brings new insights to the potential of the senescent phase for optical discrimination of low-Artic vegetation. Current and upcoming missions will exploit visible wavelength regions by providing products such as the carotenoid reflectance index (CRI) from Sentinel-2, which uses the blue and shortwave red-edge wavelengths to measure the relative carotenoid-to-chlorophyll content.

\subsection{Phenophase and Wavelength Stability of Satellite Resampled Spectra}

The results from the simulated satellite reflectance spectra suggest that EnMAP has the spectral capabilities to capture the same general trends in wavelength selection as the ground-based spectra. The simulated EnMAP reflectance spectra had the same phenological trends in cumulative ISI values by vegetation community and comparable wavelength selection as GER spectra. This suggests that the spectral resolution is capable of capturing the same vegetation pigment dynamics as described for ground-based data. This result highlights the benefit a hyperspectral imager will have for detailed characterization of tundra communities based on new spectral capabilities. This potential will have to be tested in further studies, with simulated images or with real EnMAP data taking into account 
the spatial mixing at the $30 \mathrm{~m}$ scale. Nevertheless, this study demonstrates that the EnMAP satellite has a high enough spectral resolution to be able to spectrally discriminate vegetation communities in low-Arctic regions, with similar capabilities as much higher spectral resolution (3 nm) ground-based spectral data.

The simulated Sentinel-2 spectra differed from the ground-based spectral data, as maximum canopy as opposed to senescence was the most discriminative phenophase for moist acidic tussock tundra, mossy tussock tundra, and shrub tundra communities; and leaf-out as opposed to maximum canopy was the most discriminative phenophase for moist non-acidic tussock tundra selecting. The differences in ISI values from simulated Sentinel-2 by wavelength and the resulting phenological trends could be explained by the lower spectral resolution altering the ratio of spectral variability between and within communities in some spectral regions. Although the spectral variability was different by phenological and by wavelength, blue and red-edge bands of the simulated Sentinel-2 reflectance data were still selected as the most discriminative for the differentiation of communities. The high selection in the red-edge bands suggests that Sentinel-2 data will be superior to the broadband Landsat, which has lower spectral resolution in this part of the spectrum.

\subsection{Influence of Spatial Scale}

This study examines the spectral capabilities of simulated surface spectral data from the upcoming hyperspectral EnMAP mission and the currently operational multispectral Sentinel-2, without spatial simulation equivalent to the pixel resolution of the sensors. Such a spatial simulation including real hyperspectral imagery is out of the scope of this paper and will be a topic of further research. Nevertheless, as a first approximation, we can consider that such a spatial simulation would have resulted in a considerably lower within-community spectral variability for reflectance sampled at $100 \mathrm{~m}^{2}$ (Sentinel-2 VIS and NIR bands) to $400 \mathrm{~m}^{2}$ (Sentinel-2 red-edge and SWIR bands) and up to $900 \mathrm{~m}^{2}$ (EnMAP). Indeed, the simulated sensor data show high ISI values caused by high within-community spectral variability due to sampling at a $0.15 \mathrm{~m}$ footprint spatial scale.

The aerial extent of mossy tussock tundra and moist acidic tussock tundra community patches in the Toolik Vegetation Grid are equivalent to the nominal scale of $400 \mathrm{~m}^{2}$ to $900 \mathrm{~m}^{2}$ pixels, providing pure pixels. Patches of dry tundra and moist non-acidic tundra in the Toolik Vegetation Grid occur in smaller patches but north-east of the grid these communities occur in large patches equivalent to pure pixels. Shrub tundra communities that generally occur along water tracks have lower spatial dimensions but sometimes occur in larger patches in tundra landscapes. As such, the studied communities will occur in both pure and mixed pixels of operational and future medium-resolution satellite sensors. Our study confirms a low between-community spectral variability resulting in challenging spectral classification of pure pixels as well as spectral unmixing of mixed pixels at $10 \mathrm{~m}$ to $30 \mathrm{~m}$ scales. Using ISI will support the selection of discriminative wavelength regions and indicate that a multi-phenophase approach will benefit the differentiation of spectrally similar vegetation communities at the satellite scale; in particular, the use of senescent phase EnMAP reflectance spectra in the visible, particularly blue, and red-edge spectrums, and the use of leaf-out and maximum canopy phase simulated Sentinel-2 reflectance spectra.

\section{Conclusions}

To explore the spectral variability of dominant low-Arctic tundra vegetation communities and the potential of ground-based and satellite new optical data for better discrimination and identification of different vegetation community types within tundra ecosystems, a relatively new ISI technique was used to identify the most spectrally discriminative phenophase and regions within the VNIR spectral regions. Based on field data and ISI values, we support previous findings that heterogeneous tundra ecosystems are both spectrally similar and spectrally variable, making differentiation challenging. On the other hand, our results based on the ISI technique suggest that senescence is the most discriminative phenophase for three tundra vegetation communities 
(moist acidic tussock tundra, mossy tussock tundra, and shrub tundra), which account for a majority of the study site and low-Arctic biomass at the ecosystem scale. The use of the senescent phase optical satellite data to discriminate vegetation communities has not been previously explored and is one of the major results of this paper. As with previous ground-based spectral characterization of Alaskan low-Arctic tundra on the Alaskan North Slope, the blue, red and red-edge parts of the spectrum are observed as important for vegetation community identification. Furthermore, differences in vegetation colour driven by pigment content appear to be the most discriminative areas of the spectrum to differentiate specific vegetation communities. In this paper, the phenological aspect provides an added perspective, highlighting the potential exploitation of more extreme colour differences in vegetation observed during senescence.

Our study also highlights the potential of upcoming EnMAP and operational Sentinel-2 satellites to characterize the spectral variability of tundra vegetation communities based on their spectral capabilities. The VIS and red-edge wavelength regions were the most discriminative for both sensors and, as with the ground-based data, this result suggests a multi-phenophase approach could improve differentiation at the satellite scale. Senescence was also the most discriminative phenophase for the identification of the majority of communities when using EnMAP reflectance spectra, while simulated Sentinel-2 data identified the maximum canopy as the most discriminative phenophase. The results provide insight into both the community and seasonal dynamics of spectral variability, in order to better understand and interpret currently used broadband vegetation indices and also for improved spectral unmixing of hyperspectral aerial and satellite data. This is useful for a wide range of applications, from fine-scale monitoring of shifting vegetation composition to the identification of vegetation vigor.

Supplementary Materials: The following are available online at http:/ /www.mdpi.com/2072-4292/9/11/1200/s1, Figure S1: Mean and standard deviation of simulated EnMAP reflectance spectra of five dominant tundra vegetation communities in three major phenophases of leaf-out, maximum canopy, and senescence. Figure S2: Mean (black line) and standard deviation (grey ribbon) of simulated Sentinel-2 reflectance spectra of five dominant tundra vegetation communities in three major phenophases of leaf-out, maximum canopy, and senescence.

Acknowledgments: This research was supported by EnMAP science preparatory program funded under the DLR Space Administration with resources from the German Federal Ministry of Economic Affairs and Energy (support code: DLR/BMWi 50 EE 1348) in partnership with the Alfred Wegener Institute in Potsdam. The authors would like to thank the logistical support provided by Toolik Research Station and Skip Walker of the Alaska Geobotany Center at the University of Alaska, Fairbanks. We would also like to thank Marcel Buchhorn and the HySpex Lab at the University of Alaska, Fairbanks for calibration of the spectrometer and Marcel and Skip for providing GIS data of the Toolik Area. Finally, we would like to thank Robert Guy from the Faculty of Forestry at the University of British Columbia for laboratory support and Karl Segl at the German Research Centre for Geosciences GFZ for the simulation of the EnMAP reflectance spectra.

Author Contributions: Alison Beamish and Birgit Heim conceived and designed the sampling design; Alison Beamish collected, processed, and analyzed all data; Nicholas Coops provided guidance on the analysis, and interpretation of the data; Birgit Heim and Sabine Chabrillat contributed to the interpretation of the data; Alison Beamish wrote the paper; all authors contributed valuable edits and suggestions throughout the writing process.

Conflicts of Interest: The authors declare no conflict of interest.

\section{References}

1. Bliss, L.; Heal, O.W.; Moore, J. Tundra Ecosystems: A Comparative Analysis; CUP Archive: Cambridge, UK, $1981 ;$ p. 25.

2. Walker, D.A.; Raynolds, M.K.; Daniëls, F.J.; Einarsson, E.; Elvebakk, A.; Gould, W.A.; Katenin, A.E.; Kholod, S.S.; Markon, C.J.; Melnikov, E.S.; et al. The circumpolar Arctic vegetation map. J. Veg. 2005, 16, 267-282. [CrossRef]

3. Walker, M.; Walker, D.; Auerbach, N. Plant communities of a tussock tundra landscape in the Brooks Range Foothills, Alaska. J. Veg. Sci. 1994, 5, 843-866. [CrossRef]

4. Hope, A.S.; Kimball, J.S.; Stow, D.A. The relationship between tussock tundra spectral reflectance properties and biomass and vegetation composition. Int. J. Remote Sens. 1993, 14, 1861-1874. [CrossRef] 
5. Riedel, S.M.; Epstein, H.E.; Walker, D.A. Biotic controls over spectral reflectance of arctic tundra vegetation. Int. J. Remote Sens. 2005, 26, 2391-2405. [CrossRef]

6. Buchhorn, M.; Walker, D.; Heim, B.; Raynolds, M.; Epstein, H.; Schwieder, M. Ground-based hyperspectral characterization of Alaska tundra vegetation along environmental gradients. Remote Sens. 2013, 5, 3971-4005. [CrossRef]

7. Bratsch, S.; Epstein, H.; Buchhorn, M.; Walker, D. Differentiating among four Arctic Tundra plant communities at Ivotuk, Alaska using field spectroscopy. Remote Sens. 2016, 8, 51. [CrossRef]

8. Laidler, G.J.; Treitz, P.M.; Atkinson, D.M. Remote sensing of arctic vegetation: Relations between the NDVI, spatial resolution and vegetation cover on Boothia Peninsula, Nunavut. Arctic 2008, 6, 1-13. [CrossRef]

9. Olthof, I.; Latifovic, R. Short-term response of arctic vegetation NDVI to temperature anomalies. Int. J. Remote Sens. 2007, 28, 4823-4840. [CrossRef]

10. Stow, D.A.; Hope, A.; McGuire, D.; Verbyla, D.; Gamon, J.; Huemmrich, F.; Houston, S.; Racine, C.; Sturm, M.; Tape, K.; et al. Remote sensing of vegetation and land-cover change in Arctic tundra ecosystems. Remote Sens. Environ. 2004, 89, 281-308. [CrossRef]

11. Laidler, G.; Treitz, P. Biophysical remote sensing of arctic environments. Progress Phys. Geogr. 2003, $27,44-68$. [CrossRef]

12. Boelman, N.; Stieglitz, M.; Rueth, H.; Sommerkorn, M.; Griffin, K.; Shaver, G.; Gamon, J. Response of NDVI, biomass, and ecosystem gas exchange to long-term warming and fertilization in wet sedge tundra. Oecologia 2003, 135, 414-421. [CrossRef] [PubMed]

13. Muller, S.V.; Racoviteanu, A.E.; Walker, D.A. Landsat MSS-derived land-cover map of northern Alaska: Extrapolation methods and a comparison with photo-interpreted and AVHRR-derived maps. Int. J. Remote Sens. 1999, 20, 2921-2946. [CrossRef]

14. Tucker, C. Red and photographic infrared linear combinations for monitoring vegetation. Remote Sens. Environ. 1979, 8, 127-150. [CrossRef]

15. Van Leeuwen, W.J.; Huete, A.R. Effects of standing litter on the biophysical interpretation of plant canopies with spectral indices. Remote Sens. Environ. 1996, 55, 123-138. [CrossRef]

16. Curran, P. Remote sensing of foliar chemistry. Remote Sens. Environ. 1989, 30, 271-278. [CrossRef]

17. Bartley, G.E.; Scolnik, P.A. Plant carotenoids: Pigments for photoprotection, visual attraction, and human health. Plant Cell 1995, 7, 1027-1038. [CrossRef] [PubMed]

18. Young, A.; Britton, G. Carotenoids and stress. In Stress Responses in Plants: Adaptation and Acclimation Mechanisms; Alscher, R.G., Cummings, J.R., Eds.; Wiley: New York, NY, USA, 1990; pp. 87-112.

19. Steyn, W.J.; Wand, S.J.E.; Holcroft, D.M.; Jacobs, G. Anthocyanins in vegetative tissues: A proposed unified function in photoprotection. New Phytol. 2002, 155, 349-361. [CrossRef]

20. Close, D.C.; Beadle, C.L. The ecophysiology of foliar anthocyanin. Bot. Rev. 2003, 69, 149-161. [CrossRef]

21. Chalker-Scott, L. Environmental significance of anthocyanins in plant stress responses. Photochem. Photobiol. 1999, 70, 1-9. [CrossRef]

22. Gould, K.S.; McKelvie, J.; Markham, K.R. Do anthocyanins function as antioxidants in leaves? Imaging of $\mathrm{H}_{2} \mathrm{O}_{2}$ in red and green leaves after mechanical injury. Plant Cell Environ. 2002, 25, 1261-1269. [CrossRef]

23. Guanter, L.; Kaufmann, H.; Segl, K.; Foerster, S.; Rogass, C.; Chabrillat, S.; Kuester, T.; Hollstein, A.; Rossner, G.; Chlebek, C.; et al. The EnMAP Spaceborne Imaging Spectroscopy Mission for earth observation. Remote Sens. 2015, 7, 8830-8857. [CrossRef]

24. Drusch, M.; Del Bello, U.; Carlier, S.; Colin, O.; Fernandez, V.; Gascon, F.; Hoersch, B.; Isola, C.; Laberinti, P.; Martimort, P.; et al. Sentinel-2: ESA's Optical High-Resolution Mission for GMES Operational Services. Remote Sens. Environ. 2012, 120, 25-36. [CrossRef]

25. Chance, C.; Coops, N.; Crosby, K.; Aven, N. Spectral wavelength selection and detection of two invasive plant species in an urban area. Can. J. Remote Sens. 2016, 42, 27-40. [CrossRef]

26. Somers, B.; Asner, G. Invasive species mapping in Hawaiian rainforests using multi-temporal hyperion spaceborne imaging spectroscopy. IEEE J. Sel. Top. Appl. Earth Observ. Remote Sens. 2013, 6, 351-359. [CrossRef]

27. Somers, B.; Delalieux, S.; Verstraeten, W.W.; Van Aardt, J.A.N.; Albrigo, G.L.; Coppin, P. An automated waveband selection technique for optimized hyperspectral mixture analysis. Int. J. Remote Sens. 2010, 31, 5549-5568. [CrossRef] 
28. Somers, B.; Asner, G.P.; Tits, L.; Coppin, P. Endmember variability in spectral mixture analysis: A review. Remote Sens. Environ. 2011, 115, 1603-1616. [CrossRef]

29. Peterson, S.; Roberts, D.; Beland, M.; Kokaly, R.; Ustin, S. Oil detection in the coastal marshes of Louisiana using MESMA applied to band subsets of AVIRIS data. Remote Sens. Environ. 2015, 159, 222-231. [CrossRef]

30. Walker, D.A.; Binnian, E.; Evans, B.M.; Lederer, N.D. Terrain, vegetation and landscape evolution of the R4D research site, Brooks Range Foothills, Alaska. Ecography 1989, 12, 238-261. [CrossRef]

31. Bliss, L.C.; Matveyeva, N.V. Circumpolar arctic vegetation. In Arctic Ecosystems in a Changing Climate: An Ecophysiological Perspective; Academic Press: San Diego, CA, USA, 1992; pp. 59-89.

32. Tenhunen, J.D.; Lange, O.L.; Hahn, S.; Siegwolf, R.; Oberbauer, S.F. The ecosystem role of poikilohydric tundra plants. In Arctic Ecosystems in a Changing Climate: An Ecophysiological Perspective; Academic Press: San Diego, CA, USA, 1992.

33. Lehnert, L.W.; Meyer, H.; Bendix, J. Hsdar: Manage, Analyse and Simulate Hyperspectral Data in R; R Package: Marburg, Germany, 2016.

34. Clark, R.N.; Roush, T.L. Reflectance spectroscopy: Quantitative analysis techniques for remote sensing applications. J. Geophys. Res. Solid Earth 1984, 89, 6329-6340. [CrossRef]

35. Clark, R.N.; King, T. Automatic Continuum Analysis of Reflectance Spectra. In Proceedings of the 3rd Airborne Imaging Spectrometer Data Analysis Workshop, Denver, CO, USA, 15 August 1987; NASA: Pasadena, CA, USA.

36. Somers, B.; Cools, K.; Delalieux, S.; Stuckens, J.; Van der Zande, D.; Verstraeten, W.W.; Coppin, P. Nonlinear hyperspectral mixture analysis for tree cover estimates in orchards. Remote Sens. Environ. 2009, 113, 1183-1193. [CrossRef]

37. Rock, B.N.; Hoshizaki, T.; Miller, J.R. Comparison of in situ and airborne spectral measurements of the blue shift associated with forest decline. Remote Sens. Environ. 1988, 24, 109-127. [CrossRef]

38. Walker, D.A.; Auerbach, N.A.; Shippert, M.M. NDVI, biomass, and landscape evolution of glaciated terrain in northern Alaska. Polar Rec. 1995, 31, 169-178. [CrossRef]

39. Chuvieco, E.; Martin, M.P.; Palacios, A. Assessment of different spectral indices in the red-near-infrared spectral domain for burned land discrimination. Int. J. Remote Sens. 2002, 23, 5103-5110. [CrossRef]

40. Asner, G. P. Biophysical and biochemical sources of variability in canopy reflectance. Remote Sens. Environ. 1998, 64, 234-253. [CrossRef]

41. Sims, D.; Gamon, J. Relationships between leaf pigment content and spectral reflectance across a wide range of species, leaf structures and developmental stages. Remote Sens. Environ. 2002, 81, 337-354. [CrossRef]

42. Filella, I.; Penuelas, J. The red edge position and shape as indicators of plant chlorophyll content, biomass and hydric status. Int. J. Remote Sens. 1994, 15, 1459-1470. [CrossRef]

43. Ustin, S.; Curtiss, B. Spectral characteristics of ozone-treated conifers. Environ. Exp. Bot. 1990, 30, $293-308$. [CrossRef]

44. Gitelson, A.A.; Merzlyak, M.N. Remote estimation of chlorophyll content in higher plant leaves. Int. J. Remote Sens. 1997, 18, 2691-2697. [CrossRef]

45. Gitelson, A.A.; Zur, Y.; Chivkunova, O.B.; Merzlyak, M.N. Assessing Carotenoid Content in Plant Leaves with Reflectance Spectroscopy. Photochem. Photobiol. 2002, 75, 272-281. [CrossRef]

46. Stylinski, C.; Gamon, J.; Oechel, W. Seasonal patterns of reflectance indices, carotenoid pigments and photosynthesis of evergreen chaparral species. Oecologia 2002, 131, 366-374. [CrossRef] [PubMed]

(C) 2017 by the authors. Licensee MDPI, Basel, Switzerland. This article is an open access article distributed under the terms and conditions of the Creative Commons Attribution (CC BY) license (http://creativecommons.org/licenses/by/4.0/). 